\title{
Michael Shannon, MD, MPT, FACMT, FAACT, FACEP, FAAP
}

\author{
Leslie R. Dye, MD, FACMT
}

Associate and Managing Editor, Journal of Medical Toxicology

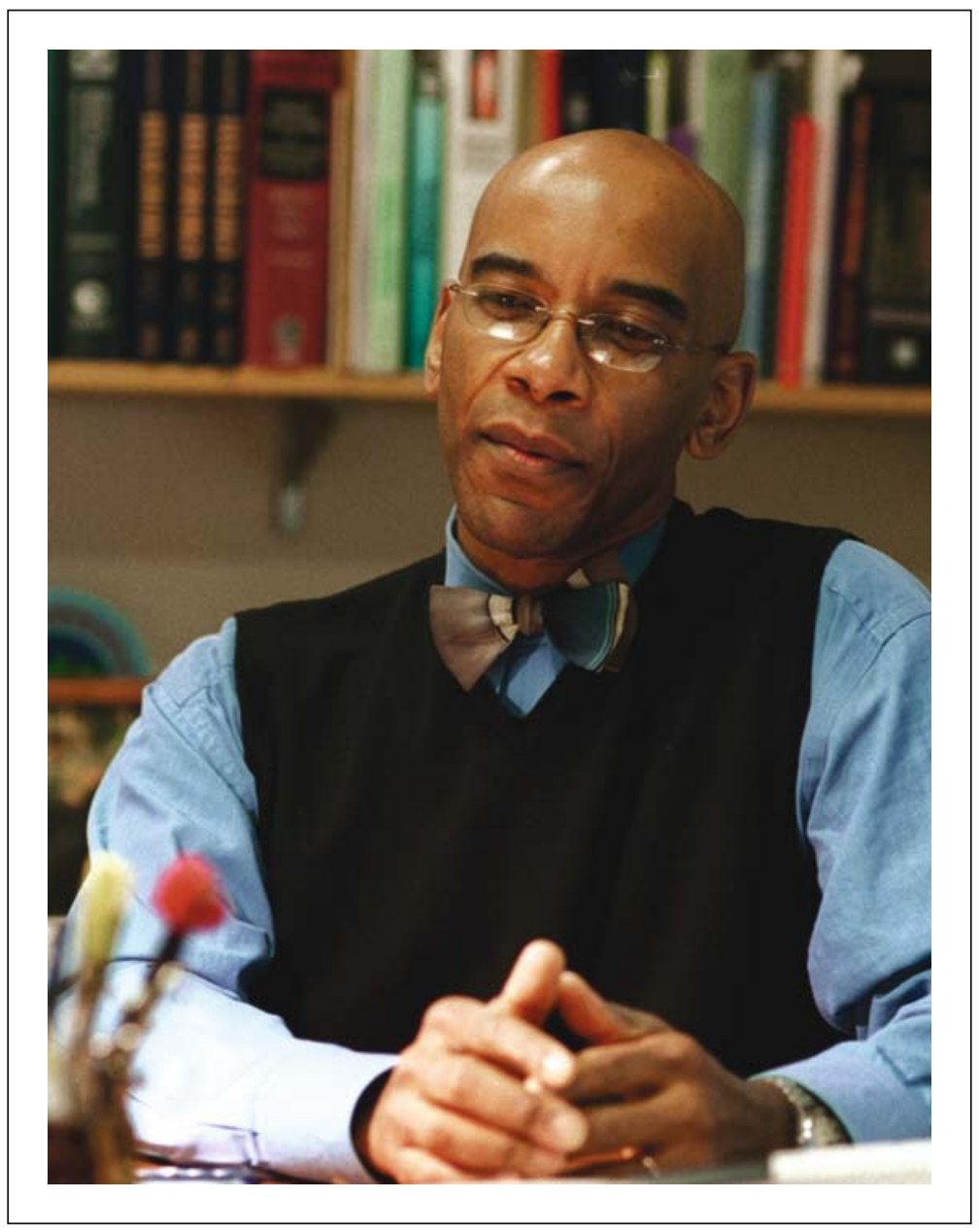

1953-2009

\section{A SHINING STAR EXTINGUISHED}

While there are plenty of wonderful things to say about Michael Shannon, this is an extremely difficult piece to write. If we can all be considered stars in the galaxy, I think each person shines differently from different angles. A mother is a shining star to her children, whether others appreciate her the same way or not. But,
Michael Shannon was a shining star from so many angles. Some of my perspective is from personal experience and some from the many tributes I have read.

He was a devoted husband, father, and son. He is survived by his wife and two children who are currently students at Stanford 
University: Evan, 21 and Lila, 20. His love for his wife, Elaine, was clear. Not only did he show it when he was with her at the annual NAACT meeting, but he dedicated a recent dance performance to "Elaine, the love of my life." Dancing was his passion that began when he attended college at Washington University in St. Louis. Not only was he a professional dancer for some years, he continued to perform every year until the time of his death. Dr. Shannon also contributed to his community. He was a board member of several charity organizations and was active in his church.

Michael was a tireless advocate for the health of children. His testimony before the FDA in Washington, DC played a role in changing labeling on children's cough and cold medications and highlighted the lack of efficacy of these products for children. His academic interests included environmental health, substance abuse, and many others.

Most of us knew Michael as a colleague and a giant in our field. His academic credentials are impeccable. After graduating from Washington University, he attended medical school at Duke University. His pediatric residency (where he was chief) and pediatric emergency medicine/medical toxicology fellowship were completed at Harvard University and Children's Hospital of Boston. He climbed all the ladders and always made it to the top. He excelled in teaching, research and service. He was a past president of ACMT, a full Professor at Harvard, the lead editor of Haddad and Winchester's Clinical Management of Poisoning and Drug Overdose, 4th Edition, and the Editor-in-Chief and Board co-chair of ToxED. He was boarded in pediatrics, pediatric emergency medicine, emergency medicine, and medical toxicology. I can't even imagine his total number of publications.
Dr. Shannon was often a lecturer for ACMT. One could reliably count on his presentations to be flawless. He combined the wellresearched, cutting edge facts with poise that most of us envied. My first major exposure to Michael was when he asked me to run for the ACMT board of directors. That is when I got to know Michael, the person. I mentioned in an online tribute that his qualities defy adequate description, due to the limits of language. I have tried to describe him to friends and family and most words are not superlative enough. Some that come close are: calm, confident, brilliant, kind, poised, caring, professional, engaging, dapper, graceful, insightful, inspirational, and a mensch. He was the type of person most of us would like to be.

Michael was a mentor for so many. Those of us who were lucky enough to know this man cannot help but be grateful. The only thing that would be worse than losing him at such an early age would be not to have known him at all. The world is a better place having had Michael Shannon with us and our galaxy will never be the same. We extend out thoughts and prayers to his family, friends, colleagues, and patients. For more tributes, go to $h t t p: / / w w w . a c m t . n e t / c g i / p a g e . c g i ? \_i d=168$.

For those who would like to make a contribution in honor of Michael's life, please consider one of the following:

Kids Clothes Club, 120 Cypress St., Brookline, MA 02445

Barro Sinplomo, c/o Ellen Carno, 16 Auburndale, MA 02466

Dr. Michael Shannon Fund for Dance,

www.bostondancealliance.org

c/o Boston Dance Alliance, Attn: Ruth Bimberg

19 Clarendon St. Boston, MA 02116 